IRA-International Journal of Education \& Multidisciplinary Studies ISSN 2455-2526; Vol.07, Issue 01 (2017)

Pg. no. 27-45

Institute of Research Advances http://research-advances.org/index.php/IJEMS

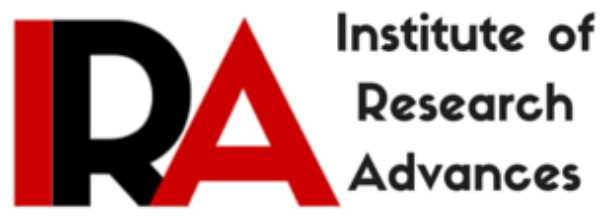

\title{
Teachers Involvement in Creation of Awareness to Members of School Community on Inclusive Education Practice in Regular Primary Schools in Siaya County
}

\author{
Odeny Michael O.Lumumba ${ }^{1}$ Adoyo Peter Oracha ${ }^{2}$ Odek Aloys Ayungo ${ }^{3}$ \\ ${ }^{1,2,3}$ School of Education Maseno University \\ Department of Special Needs and Rehabilitation \\ Private Bag, Maseno, Kenya.
}

Type of Review: Peer Reviewed.

DOI: http://dx.doi.org/10.21013/jems.v7.n1.p4

\section{How to cite this paper:}

Lumumba, O., Oracha, A. \& Ayungo, O. (2017). Teachers Involvement in Creation of Awareness to Members of School Community on Inclusive Education Practice in Regular Primary Schools in Siaya County. IRA International Journal of Education and Multidisciplinary Studies (ISSN 2455-2526), 7(1), 27-45. doi:http://dx.doi.org/10.21013/jems.v7.n1.p4

(C) Institute of Research Advances

\section{(cc) BY-No}

This work is licensed under a Creative Commons Attribution-Non Commercial 4.0 International License subject to proper citation to the publication source of the work.

Disclaimer: The scholarly papers as reviewed and published by the Institute of Research Advances (IRA) are the views and opinions of their respective authors and are not the views or opinions of the IRA. The IRA disclaims of any harm or loss caused due to the published content to any party. 


\section{ABSTRACT}

Inclusive education is a process that involves the transformation of regular schools to become accessible to all learners regardless of their diverse needs. Teachers' involvement in this transformation is significant in sensitizing members of the school community to fully participate in inclusive education practices in their respective schools. Lack of awareness about inclusive education practices has been captured in the Kenya national special needs policy framework of 2009 as a common problem. Preliminary information indicates that there is low level of advocacy and lobbying among the regular teachers, parents, communities and ministry of education officials on inclusive education practices. Baseline information shows that 48(7.52\%) regular schools in Siaya County still practice integration and learners enrolled in the special units hardly transit to mainstream classes. The rate at which learners with special needs access regular education in the county is equally very low. This is despite the presence of teachers with background training in inclusive education in the county. The purpose of the study was to determine teachers' involvement in awareness creation on inclusive education practices. Objectives of the study were to: -establish the methods teachers use to create awareness on inclusive education to members of the school communities; determine the frequency with which teachers created awareness among the members of the school communities and determine teachers' involvement in awareness creation on inclusive education. Descriptive survey research design was used for the study. The population comprised of 216 teachers and 72 head teachers. Out of which $10 \%$ were used for piloting. Saturated sampling technique was employed to select 194 teachers and 65 head teachers for the study. Instruments for data collection included Questionnaires, Interview Schedule, Observation Guide and Document Analysis. Content and face validity of the instruments were determined by experts in the school of education and their comments and recommendations were used to determine the validity of the instruments. Reliability of the instruments was established through test re-test method and correlation coefficients of 0.76 and 0.78 were obtained for teachers and head teachers respectively at a level of significance of 0.05. Quantitative data was analyzed using descriptive and inferential statistics while qualitative data was transcribed and categorized into emergent themes. The study established that teachers mostly used school forums, seminars and workshops as the main methods of creating awareness to members and that they rarely create awareness to members. The result also indicated that teachers were involved in creation of awareness to members of the school communities to a fairly small extent. The study concluded that teachers were involved in creation of awareness but not to a level that was encouraging. The study recommended that:-teachers still need to intensify the creation of awareness to members of the school community especially to parents and local members of the community for them to fully participate in inclusive education practices.

\section{Background}

Awareness is the first step in promoting positive change among the stakeholders towards inclusive education. Once people are able to recognize the benefits of inclusive education, they can begin to seek the knowledge and skills necessary to realize its goals (Inclusive School Network, 2015). Various studies on creation of awareness have focused mainly on awareness to students on disabilities and not so much on the broader concept of inclusive education to members of school communities. Disseminating information on activities that can enhance implementation of inclusive education to members of the school community is paramount. It enables the members of the school communities to effectively participate in inclusive education practices in their schools and thus consider themselves as part of the success or the challenges thereof (Lo, 2007, Carrington \& Robinson, 2004). Awareness creation builds the capacities of members in various aspects of inclusive education practices thus providing them with the knowledge and skills to be involved. Awareness programs are influential to the overall environment of a school. In schools, it is extremely important because it educates members thus making them better participants (Lindsay \& 
McPherson, 2011). Awareness programs are ways of promoting acceptance, understanding and increase knowledge about inclusive education practices (Ison et. al, 2010) which as a result, leads to the increase in interest toward inclusive education in general. Activities of awareness creation is beneficial when they incorporate hands-on practices demonstrating what is involved in inclusive education practices and transformation of a regular schools to an inclusive learning environment (McGinnis, 2006).

Studies have been done on creation of awareness, for example, Rachel (2015) studied acceptance of persons with disabilities among students at St. Cloud State University in St. Cloud, Minnesota, USA. The study hypothesized that participation in the disability awareness event would increase awareness and decrease negative stigma among participants toward persons with disabilities. Quasi-experimental research project measured the perceptions that graduate students held toward persons with disabilities. A group of approximately 100 students participated in the disability awareness event. A pretest and posttest design was administered to a non-control group before and after their participation in the disability awareness event. The results revealed a significant increase in disability acceptance among students. The study, however, restricted creation of awareness to disability and targeted only students at the university, the aim being to reduce stigma among the students towards persons with disabilities. The current study however looked at awareness creation more broadly thus targeted all members of the school community which included staff, learners, parents, board of managements and local communities, whose lack of information and skills on inclusive education would limit their participation to transform the learning environment to an inclusive setting. Furthermore the study area in the foregoing study was University; however in the current study, the area of the study was regular primary schools which form the foundation of everlasting inclusive practices including sound human values where diversity among all people is welcomed, valued and respected. It is also a reality that not only learners with disabilities are targeted for discrimination, also affected are those with other forms of special educational needs, awareness creation should therefore address issues that would be beneficial to all learners in the school environment. Awareness creation goes beyond the aspect of disability and focus on the broad perspectives which encompass all the practices that make a school inclusive (Thomsoms and Villa, 2010)

Another study on awareness creation was by Leigh et al (2013). They explored the integration of disability awareness into tertiary teaching; the study was intended to enhance disability awareness within the University of Otego Dunedu New Zealand. The result showed that little was being done to create awareness for disability among the staff. This study propagates awareness on disabilities and not inclusive education practices; this in itself reduced the process of inclusive education to a disability affair instead of broadening it to the level of inclusive education which embraces the need of all learners. Inclusive education is not about disability but for all individuals to be brought on board to create a leveled ground for everybody to participate and feel accepted and belong (Thousand and Villa, 2011). The current study therefore went further to consider awareness creation to all the members of the school community not only on disabilities but on the entire inclusive education concept, the set up of the study was carried in regular primary schools which is the foundation of early intervention on learning and development. Drame and Kamphoff (2014) in their study on perception of disability and access to inclusiveness in West Africa; A comparative case study in Dakar, Senegal, believed that to increase inclusive education for all in Senegal, the country must create community awareness campaign that increase knowledge of disabilities. Like other studies, this study concentrated on disability awareness and not the broad concept of inclusive education awareness, the current study therefore went beyond awareness of disability to inclusive education.

In another study, Williamson (2014) developed and implemented a Disability Awareness Program in a fourth grade classroom through action research design in northwest Ohio. The study determined whether the program was influential in shaping positive behaviors towards students with disabilities. The students were exposed to five disability lessons on autism, physical disabilities, dyslexia, blindness/ vision impairments and accessibility. Three lessons, beginning, middle and end, began with questionnaires on 
disability knowledge and moral thinking. Each lesson was partnered with open discussion. In response to the positive attitudes, the result showed that the classroom environment become more inclusive of students with disabilities provided a more welcoming learning environment and fostered better friendships among all students. By educating students on different disabilities, the finding indicated that they became more accepting and understanding of individual differences. The result further revealed that, the individual lessons, activities and discussions allowed students to critically think about the treatment of people with disabilities and the importance of inclusion to benefit their development and happiness. The focus of the study like other forgoing studies was on disability awareness and how to influence the overall environment of a school. It used action research design and data was collected using questionnaire. The current study however looked at awareness extensively on inclusive education practices to members of the school community. Maultiple data collection instruments including questionnaire, interview, and observation guide as well as document analysis were used to corroborate the findings of the study to ensure objectivity.

Gateru (2010) assessed teachers' awareness and intervention for primary school pupils with learning disabilities in inclusive education in Makadara Division. She used descriptive survey design with 28 teachers as the respondents and employed structured questionnaire, interview and observation scheduled as data collection instruments. The results indicated that $37 \%$ of the respondents were aware of learning disability and $63 \%$ were not aware. The study was on awareness and intervention on pupils with learning disabilities. However the current study focused on awareness creation to all members of the school community not only on learners with disabilities but including even those with other special needs.

The forgoing studies were related to the current study because they all addressed creation of awareness as an indicator of inclusive education. Studies of Rachel (2015), Drame and Kamphoff (2014) and Leigh et al (2013) all focused on creation of awareness on disabilities to students, Gateru (2010), however addressed awareness of teachers on a category of learners with disabilities. It is significantly prudent that all members of the school community be sensitized on disability matters to enable them acquire skills to manage the diverse needs of the learners and also build a school community that is inclusive in nature. A community where all members feel they belong appreciated, accepted, valued and empowered to effectively participate in various activities within and outside the school environment is a pointer to an inclusive environment.. The current study therefore went further to establish various aspects that make a school inclusive and whether such awareness resulted in building an inclusive school community. Inclusive schools change members' attitudes towards diversity and form the basis for a just, nondiscriminatory society.

\section{Statement of the Problem}

Baseline information show that $48(7.52 \%)$ regular schools in Siaya County still practice integration despite this era of inclusive education and learners enrolled in the special units hardly transit to mainstream classes. This was confirmed by having locational integrated special units in the mainstream instead of including learners fully in the mainstream, evidence showed that there were 48 (7.54\%) special units attached to the mainstream schools in Siaya County. Studies have established that few regular schools, $10(1.57 \%)$ in Siaya County have their physical environment adapted. It further established that parents still prefer to enroll their learners in special units and schools instead of regular primary schools. Data indicates that out of the 2058 learners who were assessed by EARS between 2014 and 2016 in the county, only 486 accessed their education in regular primary schools. Studies have asserted that involvement of teachers in the implementation of inclusive education is significant. This is justified by their capabilities to create awareness to the members of the school communities on inclusive education practices. Practice of integration and low level of accessibility to education in regular schools by learners with diverse needs enrolment of learners with special needs education in regular schools in Siaya County were pointers to low extent teachers were involved in creation of awareness.. 


\section{Objectives of the Study}

The objectives of the study were to:-

(i) Establish the methods teachers use to create awareness to members of the school communities.

(ii) Determine the frequency with which teachers create awareness to members of the school communities.

(iii) Determine teachers' involvement in awareness creation on inclusive education practices.

\section{RESEARCH METHODOLOGY}

The study adopted descriptive research design. It was conducted in Siaya County. The Target population comprised of 216 teachers trained in inclusive education and 72 head teachers in the sample schools. Saturated sampling technique was used to select teachers and head teachers. Sample size of this study comprised, 194 teachers and 65 head teachers in schools with teachers trained in inclusive education, (Table 2).

Table 1: Study Population and sample Frame

\begin{tabular}{lccccc}
\hline \multicolumn{1}{c}{ Category of respondents } & Target Population & Pilot Sample & Sample Size & Percentages \\
\hline Teachers & 216 & 22 & 194 & $90 \%$ \\
Head Teachers & 72 & 7 & 65 & $90 \%$ \\
& & & & \\
\hline
\end{tabular}

Source: Researcher's field data

Instruments for data collection for this study included Questionnaires for teachers and head teachers, Interview Schedule for head teachers, observation schedule and Document Analysis. Face and content validity of the instruments was determined by experts from the faculty of education to ensure that the instruments were up to standard and that there was no ambiguity. To determine the reliability of the instrument, a pilot study was conducted where of $10 \%$ (22 teachers and 7 head teachers) of head teachers and teachers were involved. These teachers were excluded from the main study. to avoid influence of prior Knowledge. Reliability of the instruments was determined through test-retest reliability method. The questionnaires were administered twice to the respondents in a span of two weeks and the results computed using Pearson Product Moment correlation. Questionnaire for head teachers yielded a reliability coefficient of 0.76 and the teachers 0.78 at a significant level of 0.05 . Quantitative data collected from close-ended questionnaire was analysed using descriptive and inferential statistics. Descriptive statistics applied included frequency counts, percentages and mean. On inferential statistics, ttest to determine if there was significant difference in the response of the teachers and head teachers was computed for specific objectives and results presented accordingly. Qualitative data from interviews, observation checklist and document analysis were coded and organized into themes from which generalizations was formulated .Key findings were recorded, interpreted, explained summarized and conclusions made. A narrative report was written and enriched with verbatim from respondents and included in the report. In the interviews respondents were assigned coded numbers to conceal their identities and the numbers were used for reporting. 


\section{Results and Discussions}

\section{Methods Teachers use to create awareness to members of the school community on inclusive education}

Teachers were asked to indicate the methods they employed to create awareness to members of the school community on inclusive education. The responses of the teachers were analyzed in frequency and percentages as shown in Table 2.

Table 2: Methods Teachers employed to create awareness to members of the school community on inclusive education $(n=194)$.

\begin{tabular}{llcc}
\hline S/N & Methods & Frequency & Percentages \\
\hline 1 & School forums & $\mathbf{9 6}$ & $\mathbf{4 9 . 5}$ \\
2 & Organizing Seminars/Workshops & $\mathbf{5 8}$ & $\mathbf{2 9 . 9}$ \\
3 & Provision of Literature & $\mathbf{3 7}$ & $\mathbf{1 9 . 1}$ \\
4 & Public Forum & $\mathbf{4 3}$ & $\mathbf{2 2 . 2}$ \\
5 & Resource Persons & $\mathbf{2 4}$ & $\mathbf{1 2 . 4}$ \\
\hline
\end{tabular}

Table 2 illustrates methods teachers used to create awareness on inclusive education to members of the school communities. From the table most teachers 96(49.5\%) reported that they used school forums and $58(29.9 \%)$ declared that they organized seminars and workshops. The least method was the use of resource persons 24(12.4\%). This implies that teachers relied on few methods instead of using as many methods as would be deemed necessary. School Forum was preferred by teachers because they spend much of their time in the schools hence had close proximity with the members within the school. This is also attributed to the challenges that teachers experience with the use of other methods. These challenges involved provision of financial and temporal resources. Considering the level of response of teachers regarding the method used, it can be concluded that majority of the members of within the community where schools are located were yet to be adequately sensitized on inclusive education. The finding concurred with that of Matlock, Fiedler, \& Walsh, (2001) who conceded that proximity in the school environment enhances collaboration between special and general teachers in sharing their expertise necessary for problem solving in inclusive education practices. Handicap International (2009) established that teachers use training, meetings and open forum to create awareness on inclusive education practices to members of the school community.

The frequency with which the teachers were involved in creation of awareness to members of the school communities

Teachers were asked to indicate how often they were involved in creation of awareness to categories of members of the school communities. The results are as shown in table 3 .

Table 3: Teachers frequency of awareness creation to members of the school communities $(n=194)$

\begin{tabular}{llllllll}
\hline S/N & Category of members & NAT & R & ST & O & V.O & M \\
\hline $\mathbf{1}$ & School Administration & $0(0.00$ & $32(16.5)$ & $56(28.9)$ & $68(35.1)$ & $38(19.6)$ & 3.58 \\
$\mathbf{2}$ & Regular Teachers & $4(2.1)$ & $62(32.0)$ & $69(35.6)$ & $36(18.6)$ & $23(11.9)$ & 3.06 \\
$\mathbf{3}$ & Parents & $48(24.4)$ & $58(29.9)$ & $52(26.8)$ & $28(14.4)$ & $8(4.1)$ & 2.43 \\
$\mathbf{4}$ & Key community informants & $79(40.2)$ & $67(34.5)$ & $42(21.6)$ & $6(3.1)$ & $0(0.0)$ & 1.88 \\
$\mathbf{5}$ & Board of Governors & $184(94.8)$ & $7(3.6)$ & $3(1.5)$ & $0(0.0)$ & $0(0.0)$ & 1.07 \\
$\mathbf{6}$ & Learners & $26(13.4)$ & $31(16.0)$ & $75(38.7)$ & $54(27.8)$ & $8(4.1)$ & 2.93 \\
$\mathbf{7}$ & Local community members & $149(76.8)$ & $33(17.0)$ & $9(4.6)$ & $3(1.5)$ & $0(0.0)$ & 1.37 \\
& Overall Mean & & & & & $\mathbf{2 . 4 4}$ \\
\hline
\end{tabular}

$\mathbf{N A T}=$ Not at all, $\mathbf{R}=$ Rarely, $\mathbf{S T}=$ Sometimes, $\mathbf{O}=$ Often, $\mathbf{V . O}=$ Very Often, $\mathbf{M}=$ Mean 
The results in table 3 show that teachers often create awareness to school administration indicated by a mean of 3.58. They sometimes create awareness to regular teachers and learners as explained by a mean score of 3.06and 2.93 respectively. They rarely created awareness to parents and key community members as shown by a mean of 2.34 and 1.88 respectively. They did not at all create awareness to local communities and to the board of governors as revealed by a mean score of 1.37 and 1.07 respectively. The overall results indicated that teachers rarely created awareness to members of the school community as proven by a mean score of 2.44. Njeri (2013) studied the role of school management committee and found that they play a significant role in procurement of teaching and learning resources; they were the legal trustee of the school, mobilization of parents, community and donors on sourcing for funds for inclusive education activities, establishing proper communication channels between the school and teachers, parents, local community members and other stake holders on the implementation of inclusive education. As the legal trustees of the school, major decision regarding school development or programmes lies with them that confirms why in this study teachers concentrated on sensitizing the administration that other members.

\section{Teachers' involvement in inclusive education practices to create awareness to members of their school communities}

Teachers were asked to indicate in the questionnaires the activities they had taken part in in their respective schools to create awareness to members of the school communities. Various activities specific to inclusive education practices were identified for the teachers to indicate how often they involved themselves in them. Data regarding involvement of teachers in the activities was collected through questionnaires, document analysis and interviews. The responses from questionnaire were as summarized in Table 4.

Table 4: Teachers involvement in the following activities to create awareness to members of their school communities $(n=194)$

\begin{tabular}{|c|c|c|c|c|c|c|}
\hline \multirow{2}{*}{ ACTIVITIES } & 1 & 2 & 3 & 4 & 5 & \multirow[t]{2}{*}{ Mean } \\
\hline & f $\%$ & f $\%$ & f $\%$ & f \% & f $\%$ & \\
\hline $\begin{array}{l}\text { Sensitize teachers on identification of learners } \\
\text { with special Needs }\end{array}$ & $73(37.6)$ & $114(58.8)$ & $7(3.6)$ & $0(0.0)$ & $0(0.0)$ & 1.66 \\
\hline $\begin{array}{l}\text { Sensitize head teachers on characteristics of } \\
\text { an inclusive school }\end{array}$ & $79(42.3)$ & $112(57.7)$ & $2(1.0)$ & $1(.5)$ & $0(0.0)$ & 1.62 \\
\hline $\begin{array}{l}\text { Help in the formation of inclusive education } \\
\text { support team in the school. }\end{array}$ & $112(57.7)$ & $82(42.3)$ & $0(0.0)$ & $0(0.0)$ & $0(0.0)$ & 1.42 \\
\hline $\begin{array}{l}\text { Organize for parents meeting to sensitize } \\
\text { parents to enroll their children with diverse } \\
\text { needs and abilities to regular schools }\end{array}$ & $91(46.9)$ & $101(52.1)$ & $2(1.0)$ & $0(0.0)$ & $0(0.0)$ & 1.54 \\
\hline $\begin{array}{l}\text { Help in the formation of community resource } \\
\text { workers to link community and schools on } \\
\text { inclusive education practices }\end{array}$ & $79(40.7)$ & $114(58.8)$ & $1(.5)$ & $0(0.0)$ & $0(0.0)$ & 1.60 \\
\hline $\begin{array}{l}\text { Organize for inclusive education days to } \\
\text { sensitize the community on inclusive } \\
\text { education }\end{array}$ & $87(44.8)$ & $105(54.1)$ & $1(.5)$ & $1(.5)$ & $0(0.0)$ & 1.57 \\
\hline $\begin{array}{l}\text { Link the school with institutions dealing with } \\
\text { special needs and other related service } \\
\text { providers to support implementation inclusive } \\
\text { education practices }\end{array}$ & $144(74.2)$ & $50(25.8)$ & $0(0.0)$ & $0(0.0)$ & $0(0.0)$ & 1.26 \\
\hline $\begin{array}{l}\text { Give talks in barazas to sensitize key } \\
\text { community leaders on inclusive education } \\
\text { practices. }\end{array}$ & $111(57.2)$ & $82(42.3)$ & $1(.5)$ & $0(0.0)$ & $0(0.0)$ & 1.43 \\
\hline $\begin{array}{l}\text { Sensitize administration on the necessity to } \\
\text { adapt school's physical environment }\end{array}$ & $69(33.5)$ & $112(62.9)$ & $6(3.1)$ & $1(.5)$ & $0(0.0)$ & 1.71 \\
\hline
\end{tabular}


$\begin{array}{lllllll}\text { Collaborate with EARS to assess learners to } & 117(60.3) & 69(35.6) & 7(3.6) & 1(.5) & 0(0.0) & 1.44\end{array}$ establish the nature of their special needs

Overall Mean

1.53

Key: 1= Very Small Extent, 2= Fairly Small Extent, 3= Small Extent, 4= Large Extent 5=Very Large Extent

Table 4 shows that to a fairly small extent $(M=1.71)$ teachers sensitized administration on the necessity to adapt school's physical environment, sensitized teachers on identification of learners with special needs $(M=1.66)$, sensitized head teachers on characteristics of an inclusive school $(M=1.62)$ and helped in the formation of community resource workers to link community and schools on inclusive education practices $(M=1.60)$. Teachers also to a very small extent gave talk in barazas to sensitize key community leaders on inclusive education practices $(\mathrm{M}=1.43)$, helped in the formation of inclusive education support team in the school $(\mathrm{M}=1.42)$ and linked the schools with institutions dealing with special needs and other related service providers to support implementation inclusive education practices $(M=1.26)$. The overall mean of 1.53 indicate that teachers were involved in creating awareness to members of the school community to a fairly small extent.

To corroborate the responses of the teachers, questionnaires on involvement of teachers in creation of awareness were given to 65 head teachers to respond to and the results were as shown in table 5

Table 5: Head teachers responses on teachers involvement in the following activities to create awareness to members of their school communities $(n=65)$

\begin{tabular}{|c|c|c|c|c|c|c|}
\hline ACTIVITIES & $1 \%$ & f $\%$ & $\begin{array}{r}3 \\
\text { f } \%\end{array}$ & $4 \%$ & $5 \%$ & Mean \\
\hline $\begin{array}{l}\text { Sensitize teachers on identification of learners } \\
\text { with special Needs }\end{array}$ & $26(40.0)$ & $39(60.0)$ & $0(0.0)$ & $0(0.0)$ & $0(0.0)$ & 1.60 \\
\hline $\begin{array}{l}\text { Sensitize head teachers on characteristics of an } \\
\text { inclusive school }\end{array}$ & $28(43.1)$ & $35(53.8)$ & $2(3.1)$ & $0(0.0)$ & $0(0.0)$ & 1.60 \\
\hline $\begin{array}{l}\text { Help in the formation of inclusive education } \\
\text { support team in the school. }\end{array}$ & $39(60.0)$ & $26(40.0)$ & $0(0.0)$ & $0(0.0)$ & $0(0.0)$ & 1.40 \\
\hline $\begin{array}{l}\text { Organize for parents meeting to sensitize } \\
\text { parents to enroll their children with diverse } \\
\text { needs and abilities to regular schools }\end{array}$ & $32(49.2)$ & $33(50.8)$ & $0(0.0)$ & $0(0.0)$ & $0(0.0)$ & 1.51 \\
\hline $\begin{array}{l}\text { Help in the formation of community resource } \\
\text { workers to link community and schools on } \\
\text { inclusive education practices }\end{array}$ & $29(44.6)$ & $36(55.4)$ & $0(0.0)$ & $0(0.0)$ & $0(0.0)$ & 1.55 \\
\hline $\begin{array}{l}\text { Organize for inclusive education days to } \\
\text { sensitize the community on inclusive education }\end{array}$ & $37(56.9)$ & $28(43.1)$ & $0(0.0)$ & $0(0.0)$ & $0(0.0)$ & 1.43 \\
\hline $\begin{array}{l}\text { Link the school with institutions dealing with } \\
\text { special needs and other related service } \\
\text { providers to support implementation inclusive } \\
\text { education practices }\end{array}$ & $65(100.0)$ & $0(0.0)$ & $0(0.0)$ & $0(0.0)$ & $0(0.0)$ & 1.00 \\
\hline $\begin{array}{l}\text { Give talks in barazas to sensitize key } \\
\text { community leaders on inclusive education } \\
\text { practices. }\end{array}$ & $35(53.8)$ & $30(46.0)$ & $0(0.0)$ & $0(0.0)$ & $0(0.0)$ & 1.46 \\
\hline $\begin{array}{l}\text { Sensitize administration on the necessity to } \\
\text { adapt school's physical environment }\end{array}$ & $17(26.2)$ & $48(73)$ & $0(0.0)$ & $0(0.0)$ & $0(0.0)$ & 1.74 \\
\hline $\begin{array}{l}\text { Collaborate with EARS to assess learners to } \\
\text { establish the nature of their special needs }\end{array}$ & $37(56.9)$ & $28(45.1)$ & $0(0.0)$ & $0(0.0)$ & $0(0.0)$ & 1.43 \\
\hline Overall Mean & & & & & & 1.47 \\
\hline
\end{tabular}

Key: 1= Very Small Extent, 2= Fairly Small Extent, 3= Small Extent, 4= Large Extent 5= Very Large Extent 
The response from head teachers show that teachers to a fairly small extent were involved in sensitizing administration on the necessity to adapt school's physical environment $(M=1.74)$, sensitize teachers on identification of learners with special Needs $(M=1.60)$ and sensitize head teachers on characteristics of an inclusive school $(\mathrm{M}=1.60)$. In addition the head teachers also indicated that to a very small extent, teachers were involved in helping in the formation of inclusive education support team in the school $(\mathrm{M}=1.40)$, organizing for inclusive education days to sensitize the community on inclusive education ( $\mathrm{M}=$ 1.43) and collaborating with EARS to assess learners to establish the nature of their special needs $(\mathrm{M}=1.43)$. The overall mean of 1.47 indeed confirmed that to a fairly small extent, teachers were involved in creation of awareness.

The study is in concurrence with the thinking of Sergiovanni, (2009) who believed that sensitizing school administrators is significant in achieving successful inclusive education practices. The role of teachers with inclusive education training background include helping learners, staff, and parents to think and act more inclusively, guide and support the course of change, drawing together the resources and people necessary for inclusive education to be successful, guide the school to increase its capacity to respond to the varying learning styles and abilities of its learners and work in collaboration with school administration to create and maintain a school climate in which all learners can feel a sense of identity, belonging, and place. The study is equally in agreement with the findings of DiPaola \& Walther-Thomas, (2003) that the school knowledge and skills in inclusive education should design, lead, manage and implement programs for all learners in an inclusive setting. Research consistently demonstrates that without effective leadership for inclusive education, success is difficult to achieve. Leaders must be knowledgeable supporters of inclusion who provide caring support for their staff (Hoppey \& McLeskey, 2013; Forlin, 2013).

In one of the study finding, it was noted that the principal was usually the first contact person at a school and, in some cases, unequivocally stated that children with disabilities were not admitted. The reasons given by these principals were related to issues such as the training of teachers, class sizes, inaccessible school buildings and other parents' and teachers' reactions. It therefore appears that these principals did not know exactly what inclusive education is.( Eloff, ., Engelbrecht, ., Kozleski, ., Oswald, ., Swart, . \& Yssel, . 2002). According to Stainback and Stainback (2009), an inclusive school is a place where everyone belongs, is accepted, supports, and is supported by his or her peers and other members of the school community in the course of having his or her educational needs met. As much as the result shows that there was frequent involvement in sensitizing head teachers on characteristics of an inclusive school and sensitizing administration on the necessity to adapt schools' physical environment, few teachers were involved in these activities, this implied that most head teachers in regular primary schools in Siaya County had not been sensitized hence were still ignorant of how an inclusive school should look like.

The results indicate that majority of the teachers were to a very small extent involved in activities that create awareness to members of the school community, notable ones being sensitizing parents on the need to enroll their children with diverse needs and abilities to regular schools, helped in the formation of inclusive education support team in their schools and helping in the formation of community resource workers to link community and schools on inclusive education practices.

Parents' involvement in the schools' inclusive education practices is very significant Epstein (2009) established six levels in which school may involve parents in its activities, these include: assisting parents in acquire skills to manage special needs of their children, communicating with parent on inclusive education practices, involving parents in school volunteer to participate in inclusive education practices, involving parents in home-based learning activities to support learners with inclusive education, involving parents in school decision-making, and involving parents in school-community collaborations. These activities bring parents closer to the schools and make them feel welcome to participate in school issues as a key member. 
UNICEF (2014) outlines gains that parental involvement would bring to the school, these include; increase in interaction with their children, become more responsive and sensitive to their needs and more confident in their parenting skills, educators acquire a better understanding of families' culture and diversity, feel more comfortable at work and improve their morale. Schools, by involving parents and the community, tend to establish better reputations in the community. Teachers' lack of involving parents in inclusive education practices undermines their interest to enroll their children with disabilities in regular primary schools (Narang \& Agarwal, 2011). Parents need to work with the school to ensure that all out-of school children are found, enrolled in school and continued to learn well (MOE, 2010).

The involvement of communities is important for getting all children in school and helping them to learn successfully, community also offer information and practical knowledge that school can use to enhance the teaching and to promote learning, to mobilize the resources needed to improve learning for all children, to improve the quality of the schools and in order to achieve sustained, lasting change, schools have to work together with communities. Communities have therefore proved to be valuable resources for schools in transforming the school environment to that which is child friendly in nature (Rieser, 2008, Shaklee, Luckey, Traver, Tifft, and Hampton, 2010). The result of the study, nevertheless, revealed that majority of teachers in regular schools in Siaya County are not involve in activities that sensitized communities on inclusive education practices such as forming community resource workers to link school and communities. This minimized active participation of community members in inclusive education practices in the school.

A link between the school and the communities has recognizable benefits such as improved relationships between the community and both teachers and the learners, members of the communities monitor activities that go on in the school by visiting, identifying and resolving any issue affecting inclusive education practices, furthermore, through resource mobilization, the communities help in purchasing learning materials as a way of involving in their children's education and communities also are involved in developing and enforcing policies that are in line with creating an inclusive school ( Azzopardi, 2011). Teachers and head teachers were asked to rate the level of teachers' involvement in awareness creation. The questionnaires were administered to the respondents and analysis done on a five point scale as follows:- ((1.0 to 1.44- Very small extent, 1.45 to 2.44 - Fairly small extent, 2.45 to 3.44 - small extent ,3.44 to 4.44- Large extent, 4.45 to 5.0 -Very large extent. The mean of the two categories of the respondents was calculated and the difference in the two means determined using a sample t-test

Table 6: Teachers and Head teachers rating of the level of teachers' involvement in creating awareness to members of the school communities $(n=194 \& 65)$

\begin{tabular}{|c|c|c|c|}
\hline $\mathbf{S} / \mathbf{N}$ & ACTIVITIES & Mean1 & Mean2 \\
\hline 1 & Sensitize teachers on identification of learners with special Needs & 1.66 & 1.60 \\
\hline 2 & Sensitize head teachers on characteristics of an inclusive school & 1.61 & 1.60 \\
\hline 3 & Help in the formation of inclusive education support team in the school & 1.42 & 1.40 \\
\hline 4 & $\begin{array}{l}\text { Organize for meeting to sensitize parents to enroll their children with } \\
\text { diverse needs and abilities to regular schools }\end{array}$ & 1.54 & 1.51 \\
\hline 5 & $\begin{array}{l}\text { Help in the formation of community resource workers to link community } \\
\text { and schools on inclusive education practices }\end{array}$ & 1.60 & 1.55 \\
\hline 6 & $\begin{array}{l}\text { Organize for inclusive education days to sensitize the community on } \\
\text { inclusive education }\end{array}$ & 1.57 & 1.43 \\
\hline 7 & $\begin{array}{l}\text { Link school with institutions and other related service providers to support } \\
\text { inclusive education practices in the school }\end{array}$ & 1.26 & 1.00 \\
\hline 8 & $\begin{array}{l}\text { Give talks in barazas to sensitize key community leaders on inclusive } \\
\text { education practices }\end{array}$ & 1.43 & 1.46 \\
\hline 9 & Sensitize administration on the necessity to adapt school's physical & 1.69 & 1.74 \\
\hline
\end{tabular}


environment

Collaborate with EARS to assess learners to establish the nature of their $1.44 \quad 1.43$

special needs.

Mean

\section{Key: M1= Teachers response, M2= Head teachers response}

Table 6 indicates that the involvement of teachers in the activities for inclusive education practices was to a fairly small extent. The leading activities was Sensitizing administration on how to adapt school's physical environment recorded mean score of 1.69 and 1.74, sensitizing teachers on identification of learners with special need with a mean of 1.66 and 1.60 , sensitizing head teachers on characteristics of an inclusive school with a mean of 1.62 and 1.60 . The least activity was linking school with institutions and other related service providers to support inclusive education practices in the school which had a mean of 1.26 and 1.00 .

To determine the significant differences in the mean of teachers and head teachers, a sample t-test was conducted and the result is as shown in Table 7 and 8

Table 7: Group Statics: Mean differences of Teachers and Head teachers on creation of awareness

\begin{tabular}{lccccc}
\hline & Respondents & N & Mean & Std. Deviation & $\begin{array}{c}\text { Std. } \\
\text { Mean }\end{array}$ \\
\hline Creation & of Teachers & 194 & 16.2268 & 4.65828 & .33445 \\
Awareness & head teachers & 65 & 16.7231 & 2.41420 & .299414 \\
\hline
\end{tabular}

The results in table 7 indicate that the difference in the means of teachers $(M=16.2268)$ and head teachers $(\mathrm{M}=16.7231)$ was -.4963 with 2.66 and 2.41 standard deviations respectively. This implies that there was minimal variance in the response in awareness creation of head teachers and teachers. It was therefore necessary to find out whether the differences were significant. An independent sample t-test was therefore used to compute the significance of these differences.

Table 8: The difference in the responses in the Teachers and Head teachers on teachers' involvement in the Awareness Creation on Inclusive Education

\begin{tabular}{lllcccc}
\hline & F & Sig & t & df & $\begin{array}{c}\text { Sig } \\
\text { (2-tailed) }\end{array}$ & Mean Difference \\
\hline $\begin{array}{l}\text { Equal variance } \\
\text { assumed }\end{array}$ & 67.329 & .000 & -822 & 257 & .412 & -.49627 \\
$\begin{array}{l}\text { Equal variance } \\
\text { not assumed }\end{array}$ & & & -1.106 & 213.232 & .270 & -.49627 \\
\hline
\end{tabular}

From Table 8 it is evidence that there was no significant difference in the teachers and head teachers' scores of teachers' involvement in the creation of awareness on inclusive education $\mathbf{t}(\mathbf{2 1 3 . 2 3 2})=\mathbf{- 1 . 1 0 6}$; $\mathbf{p}>\mathbf{. 0 5})$. This meant that both teachers and head teachers responses indicated that there was a very low involvement of teachers in creation of awareness to members of the school community on inclusive education. This finding is consistent with that of Sudha and Indu (2015) on effect of inclusive education awareness programme on pre-service teachers. They found no significant difference in the pretest scores of experimental and control group on awareness of inclusive education $(\mathbf{t}=\mathbf{0 . 4 7} ; \mathbf{p}>\mathbf{0 . 0 5})$.

Kafia, (2014) asserts that to implement inclusive education and be successful with it, teachers should have a certain level of knowledge about inclusive education which they can use in identifying children with special needs and also manage them accordingly. The results in Table 6 show that sensitization of teachers on basic inclusive education techniques generated a mean of 1.54 and 1.43 which was a very low 
rating. This compromised the competency of the teacher in the management the needs of learners in an inclusive setting. Gateru's (2011) found that teachers are able to use corrective approaches, provide options for pupils to demonstrate their knowledge or skills and accommodate individual differences among the pupils. All this is possible with appropriate knowledge and skills derived from inclusive education techniques

Rachel (2005) and Drame and Kamphoff (2014) both concurred with Kafia that creating awareness on inclusive education to members of school community would increase their knowledge on issues regarding disabilities and special needs. Despite the recognition of the importance of sensitization of the members of the school community, the results revealed that teachers had not done much to create awareness on inclusive education to key members of the community which generated a mean of 1.43 and 1.46 respectively from teachers and head teachers responses, which is a very low rating in terms of teachers involvements in inclusive education practices. These are significant people in key decision making in the schools hence require in depth knowledge on all aspects of important matters on school affairs including inclusive education. DiPaola and Chriss (2009) observe that the school administrator's role is pivotal in the special education process; however, they noted that few school leaders are well prepared for this responsibility.

In summary, with regard to the first objective which was to determine teachers' involvement in awareness creation on inclusive education practices, the results indicated that teachers' involvement in the creation of the awareness on inclusive education practices to members of the school community was fairly to a small extent based on the rating scales set to measure the extent of teachers involvement.

The head teachers were asked to state the nature of activities that teachers were involved in to create awareness to members of the school communities. The results are shown in the table 9.

Table 9: Head teachers' response on Teachers involvement in activities to create awareness to members of the school communities. $(n=65)$

\begin{tabular}{|c|c|c|c|}
\hline S/N & Activities & Frequency & Percentage \\
\hline 1 & $\begin{array}{l}\text { Number of teachers that sensitized regular teacher on identification of } \\
\text { learners with diverse needs }\end{array}$ & 28 & 14.4 \\
\hline 2 & $\begin{array}{l}\text { The number of teachers that sensitize head teachers on characteristics } \\
\text { of an inclusive school. }\end{array}$ & 18 & 27.7 \\
\hline 3 & The number of schools with inclusive education support team & 08 & 12.3 \\
\hline 4 & $\begin{array}{l}\text { The number of teachers that organized parents meeting to sensitize } \\
\text { them on inclusive education practices }\end{array}$ & 12 & 6.2 \\
\hline 5 & The number of schools with community resource workers & 03 & 4.6 \\
\hline 6 & $\begin{array}{l}\text { The number of schools that have organized inclusive education days } \\
\text { to sensitize local community on inclusive education practices }\end{array}$ & 12 & 18.5 \\
\hline 7 & $\begin{array}{l}\text { The number of schools with linkages with institutions dealing with } \\
\text { special needs matters and other related service providers to support } \\
\text { the implementation of inclusive education practices with }\end{array}$ & 02 & 3.1 \\
\hline 8 & $\begin{array}{l}\text { The number teachers who have sensitized key community leaders on } \\
\text { inclusive education practices }\end{array}$ & 02 & 3.1 \\
\hline 9 & The number of schools with adapted physical school environment & 08 & 12.3 \\
\hline 10 & $\begin{array}{l}\text { The number of teachers involved in the assessment of learners with } \\
\text { diverse needs by the EARS }\end{array}$ & 35 & 18.0 \\
\hline
\end{tabular}

The results in table 9 show indicators of teachers' involvement in activities that create awareness as provided by the head teachers. From table 9 it is evident that 28(14.4\%) teachers sensitized regular teachers on identification of learners with special needs in their classes. It also revealed that $18(27.7 \%)$ 
teachers sensitized head teachers on the characteristics of an inclusive school. The result equally revealed that $12(18.5 \%)$ teachers organized parents meeting to sensitize them on inclusive education practices a similar number organized inclusive education days to sensitize local community on inclusive education practices. The findings also indicate that teachers sensitized 35(18.0\%) regular primary school teachers in the sample schools on how to identify learners with diverse needs in the learning environment. Based on the indicators in the table, head teachers observed that teachers were least involved in encouraging schools to form community resource workers 3(4.6\%) who play significant role of linking schools with community members on inclusive education related activities (Ogot, 2014) and sensitizing key community leaders sensitized in inclusive education practices $2(3.1 \%)$. Community resource workers support inclusive education activities in that; they take data from the community on children with diverse needs who are not enrolled in the schools and collaborate with school, community members and parents of the children to secure enrollment for them, disseminate information on inclusive education to members of the school community, guide and counsel parents and members on the need to accept their children with special needs and enroll them in schools, help in mobilizing the resources from members of the communities for inclusive education activities in the school, keep record of individuals with special needs in the community and the related service they receive and sensitizing members of the communities on inclusive education in informal gatherings (Watson, \& Battistich, 2006). Inaction by teachers to encourage their respective schools to form community resource workers has denied schools and communities such noble role as cited in Watson et al (2006).

Other areas that head teachers noted least involvement by teachers were in helping schools to have linkages with institutions dealing with special needs matters and other related service providers to support the implementation of inclusive education practices $2(3.1 \%)$

The results from the interview with head teachers indicate that teachers kept records of learners with diverse needs in their classes. In 4 schools, the head teachers concurred that during admission of the learners, parents and guidance are guided by teachers to fill in a prescribed form (Table 28) in which they are required to declare if their children have any form of special needs. In addition, it enables teachers to identify learners with learning difficulties in their respective classes through observation, interviewing those who are close and interact with the learners as well as through administration of test tools.

One head teacher had this to say on identification of learners with diverse needs

"Identification of learners with special needs require keen observation and patience from

the teachers, some of these learners do not wish to be associated with disabilities, however,

through experience, it is easy to identify them"'(HT 4)

On characteristics of an inclusive school, some of the head teachers who responded had these to say:-

An inclusive school is that which accept all the learners regardless of their individual

differences (HT 6)

An inclusive school is that which make the necessary adjustment to accommodate

individual with impairment/disabilities to enable them access both social and physical

environment (HT 9) 
"An inclusive school is characterized by adapted physical environment, flexible curriculum and enhances school community linkages and partnerships' (HT 12)

The general impression from the above responses is that head teachers understood how they should transform their ordinary regular schools to that with an inclusive learning outlook. However, considering the result in table 9, only $18(27.7 \%)$ out of 65 head teachers had been sensitized by teachers on characteristic of an inclusive school. This implies that majority of head teachers in Siaya County still require adequate information about how to make a regular school become inclusive in nature.

On adaptation of schools' physical environment, head teachers acknowledged that much still need to be done, the result indicated that only $8(12.3 \%)$ schools out of the 65 sampled had their physical school environment adapted through building ramps, adapting toilets, leveling the playground and making entrance to the building wide enough to be accessed by wheelchair.

Head teachers of the 8 schools that consented of having inclusive education support team indicated that the teams had been useful in mobilizing parents of children with diverse needs for admission to regular schools in the community, make follow-ups on children with diverse needs who are out of schools for re admission, guide and counsel parents of children with disabilities to appreciate their children and provide them with the necessary support, encourage members of the school community to participate in inclusive education practices in the school and to sensitize members of the local communities. Despite such important role, it only 8 (12.3\%) schools had such arrangement in the county, leaving out $87.7 \%$ s without experiencing the benefits of inclusive education support team as stated by the head teachers.

The interview results revealed that inclusive education day is such an important activity in the calendar of schools that practiced it. In response to the enquiry about the some of the activities that the schools organized during such event to sensitize members of the local communities on inclusive education practices, they identify the following activities:-

i) Drama activities with themes on special needs

ii) Poems embracing the importance of inclusion

iii) Adapted physical education

iv) Songs conducted in Kenya Sign Language

v) Exhibition of artwork from learners with diverse needs

vi) Ball games involving learners with and without disabilities.

vii) Reading and writing in Braille

viii) Interpretation of speeches for those with hearing impairments among the audience.

One head teacher when appreciating the need to organize inclusive education days had this to say:

"The event has demonstrated that learners with disabilities have a lot of hidden potentials that would have gone to a waste had such learners not been enrolled in the school" (HT 2)

Another head teacher acknowledged the need to have such event in the schools by stating as follows:-

"Inclusive education days are very important for sensitizing the public on what learners with special needs are capable of doing when given opportunity and the appropriate environment to do so" (HT 9)

The head teachers however showed variance on the frequencies of organizing such events. Majority (6 schools) organized the event once a year; the other 2 schools were non committal but indicated that they held it when money was available.

On collaboration with related service providers, all the 7 head teachers conceded that they were in good working relationship with Education Assessment and Resource Service (EARS) providers. The main 
activity of EARS is to work with classroom teachers to identify and assess learners with limitation in their cognitive, sensory, physical and emotional functions and recommend appropriate support for them. They equally support regular teachers in the management of learners with diverse needs, especially in the adaptations of teaching and learning strategies. Head teachers of 2 schools however, revealed that they collaborate with physiotherapists from sub-counties' health centres to provide support required by learners with disabilities.

The records existing in the schools were examined to identify evidence of the involvement of teachers in creation of awareness to members of the school community. The result is as in table 10 .

Table 10: Summary of Indicators of teachers' involvement in activities to create awareness to members of the school community ( $n=65$ schools)

\begin{tabular}{|c|c|}
\hline ACTIVTIES & INDICATORS \\
\hline $\begin{array}{lll}\text { Sensitize } & \text { head } & \text { teachers } \\
\text { characteristics of an inclusive school. }\end{array}$ & $\begin{array}{l}\text { Documents observed in the schools show that } 18 \text { head teachers were } \\
\text { sensitized between July } 2015 \text { and February } 2016 \text { on characteristics of an } \\
\text { inclusive school. }\end{array}$ \\
\hline $\begin{array}{l}\text { Organize parents meeting to sensitize } \\
\text { them on inclusive education practices }\end{array}$ & $\begin{array}{l}\text { The documents verified from a school with such records showed that } \\
\text { teachers organized for a parent meeting on } 29 \text { TH FEBRUARY, 2015to } \\
\text { sensitize parents on inclusive education practices. The record showed } \\
\text { that } 16 \text { parents attended occasion and were sensitized on }\end{array}$ \\
\hline & i. Characteristics of learners with special needs \\
\hline & Care of learners with special needs \\
\hline & $\begin{array}{l}\text { Related services and specialized equipment needed by learners } \\
\text { with special needs. }\end{array}$ \\
\hline & Identification of children with special needs \\
\hline & v. Benefits of inclusive education \\
\hline
\end{tabular}

Sensitize teachers on identification of learners with special Need

Conduct sensitization of key community members on benefits of inclusive education

Collaborate with EARC to assess learners for early intervention
The document analyzed showed that teachers were sensitized on identification of learners with special needs on 1STMARCH, 201512 teachers attended the sensitization.

Analysis revealed that three one- day workshops were organized to participants in Nov, 2015 including 3 assistant chiefs, 2 religious leaders and 3 village elders were trained on barriers to the inclusion.

Documents analyzed showed a list of 148 learners who had been formally assessed by EARCs in collaboration with 35 teachers between May 2013 and March 2016.

Tables 10 show summary of indicators of teachers' involvements in creation of awareness to members of the schools communities. The information summarized was extracted from the documents found in the files of inclusive education activities presented to the researcher by the administration of fourteen schools.

The teachers were interviewed to establish the needs for these activities. On sensitization of head teachers on characteristics of an inclusive school, the teachers said it helped to raise the awareness and understanding of the inclusive education concept and lead to a change of attitude among heads of schools them being administrators and managers respectively. They concurred that head played a key role in supporting the implementation of the Inclusive Education activities in their schools.

One of the teachers gave the following comment about his head teacher:-

My head teacher had negative attitudes towards CWDs, but since the training, he

has been positive, he is now willinging to allocate resources to support the CWDs, for example the additional 2000 KSHS per child that is given to CWDS is

being utilized in meeting some of the specific needs of CWDS in the schools(T8)

Another teacher said the following about her head teacher:-

I am a happy person nowadays because my head teacher has gained confident 


\section{to closely monitor and supervise the support given to CWDs in the school (T12)}

This conformed to Salisbury (2006) who acknowledges that principals and other administrative officials play a critical role in creating conditions necessary for inclusive education practices to be implemented in their school systems. This view is congruent with Njeri's (2013) who found out that school management boards were capable of mobilizing resources from members of the school community for the implementation of inclusive education..

On sensitization of teachers to identify of learners with special Need, teachers' narrated training of teachers in inclusive education has led to positive change seen in the support received by CWDs in the classrooms. Teachers also had acquired technique to organize classroom environment for learners with special needs as demonstrated in a change in seating arrangements adopted in a number of classrooms from traditional vertical columns to inclusive seating arrangements (children with disability sitting in groups with the other students), the development of locally made teaching and learning materials that utilize a variety of senses including visual and tactile senses and the adoption of the Individualized Education programmes (IEP) for CWD. Cook (2001) pointed out that the success or failure of inclusive programming is significantly dependent on the teachers who implement it. Most importantly, teachers have the opportunity to make a difference in all of their students' lives (Cook, 2001).

On conducting sensitization of key community members, the teachers said that awareness initiatives have increased the community's knowledge of inclusive education and also general awareness about disability in the community.

On collaborate with EARC to assess learners for early intervention, teachers said that assessment enables classroom teachers to early identify and intervene on the diverse needs in their classes. It also enables the learners to benefit from services from other professionals on the needs that are beyond the teachers' management.

The researcher also carried out observation to establish the indicators of awareness creation based on inclusive education practices existing in the sample schools. An accessibility observation conducted in sixteen showed that 8 schools had ramps, foot paths, adapted toilets, and leveled play ground. There were rails in the toilets to support the members with disabilities, there was also enough space for those on a wheelchair and the entrance to the buildings had ramps. This made it possible for children with and without disability to move in the school with minimal assistance.

\section{Conclusions and Recommendations}

\section{Conclusions}

Teachers were involved in creation of awareness but to a fairly small extent furthermore activities organized by the teachers to create awareness concentrated much within the schools than in other settings such as the communities.

\section{Recommendations}

The study recommended that:-

Teachers still need to intensify the creation of awareness to members of the school community especially to parents and local members of the community.

\section{References}

1. Carrington, S., \& Robinson. (2014). Learning about inclusion from developing countries: Using the Index for inclusion. In C. Forlin \& T. Loreman (Eds.), Measuring inclusive education (Vol. 3). International Perspectives on Inclusive Education. Bingley, UK: Emerald Group Publishing Limited. 
2. DiPaola ,M. F. and Chriss W. (2003) Principals and Special Education: The Critical Role of School Leaders. Center on Personnel Studies in Special Education and the National Clearinghouse for Professions in Special Education.

3. Drame, R. E \& Kamphoff, K. (2014).Perception of disability and access to inclusive in West Africa. International Journal of special education vol. 29 No. 3, 2014.

4. Forlin, C. (2013). Issues of inclusive education in the 21st century. Journal of Learning Science, 6,6781 .

5. Gateru, W (2010). Teachers' awareness and intervention for primary school pupils with learning

6. disabilities in inclusive education in Makadara Division. Unpublished Master's Thesis:

7. Kenyatta University. Downloaded on $20^{\text {th }}$ May. 2015.

8. Government of Kenya (2009). National Special Education Policy Framework. Nairobi: Government Printers.

9. Inclusive School Network (2015). Great Things Happen in Inclusive Schools. Celebration Activities for Inclusive Schools Week.www.inclusiveschools.org Down Loaded on $10^{\text {th }}$ October, 2015.

10. Ison, N., McIntyre, S., Rothery, S., Smithers-Sheedy, H., Goldsmith, S.,\& Parsonage, S., (2010). 'Just Like You': A Disability Awareness Programme For Children That Enhanced Knowledge, Attitudes And Acceptance: Pilot Study Findings. Developmental Neuro-rehabilitation, 13, 360-368

11. Kafia, E (2014). Teachers and Parents awareness; A key factor to success of inclusive education. European Scientific Journal Vol. 10, No. 28, 2014, ISSN 1857- 7881.

12. Kelly, B. (2005). The learning experiences of students with moderate and high needs in regular

$i$. and special education settings. Building capability in education for students with

ii. moderate and high needs. A literature review (pp. 167-195). Wellington, New Zealand: Ministry of Education.

13. Leigh, H., Meer. J.V, Rutherford, G. \& Lynne, C,J( 2013). Exploring the integration of Disability awareness into Tertiary. Journal of Education and Learning Vol. 2 No. 1, 2013.

14. Lindsay, S \& McPherson, A. C.,. (2011). Strategies For Improving Disability Awareness And Social Inclusion Of Children And Young People With Cerebral Palsy. Child:

15. Care, Health and Development, 38, 809-816

16. Lindsay, S., \& Edwards, A. (2013). A systematic review of disability awareness interventions for children and youth. Disability \& Rehabilitation, 35(8), 623-646.

17. Lo, Leslie Nai-Kwai. (2007). The sustainable development of inclusive education. Chinese Education and Society, 40(4), 44-62.

18. Louise . C. (2013) A Case Study Examining the Inclusion of Childrenwith Special Educational Needs in a Mainstream Primary School. Dublin: Trinity College Dublin

19. Loreman, T. (2013). Measuring inclusive education outcomes in Alberta, Canada. International Journal of Inclusive Education, 18(5), 459_483. doi:10.1080/13603116.2013.788223.

20. Maina, J, I, (2014), Influence of head teacher leadership development on implementation of inclusive education in public primary schools in kiambu county, Kenya. Unpublished 
Thesis, University of Nairobi

21. Manzi, T.M (2008). Effectiveness of implementation of inclusive education in primary schools in Mwingi District, Kenya. Unpublished Master thesis, Kenyatta University.

22. Manandu, M, T (2011) Effectiveness of the implementation of inclusive education in primary schools in mwingi district, keny. Unpublished Master thesis, Keyatta University

23. Mastropieri, M. A., Scruggs, T. E., \& Berkeley, S. L. (2007). Peers helping peers. Educational Leadership, 64(5), 54-58.

24. McGinnis, J. (2006). Elementary School and University Collaboration for a Disability Awareness Workshop. Delta Kappa Gamma. 28-30

25. Miles, S. and Singal, N. (2010) "The Education for All and Inclusive Education Debate:Conflict,Contradiction or Opportunity?" International Journal of Inclusive Education,14(1): 1-15.

26. MOE (2010). Data on regular primary schools' staffing and enrolment in Siaya County. Siaya: Staffing Department.

27. MOE and LCD (2011). A survey on implementation of inclusive education in Nyanza. Nirobi: Cheshire.

28. Mitchell, D. (2008). What really works in special and inclusive education: Using evidence-based teaching strategies.Abingdon, Oxon: Routledge

29. Ministry of Educaton (2013). Data showing number of schools, staffing and enrolment in the Siaya County. Siaya: District Staffing Office.

30. Ministry of Education Science and Technology (2003). Introduction to Inclusive Education Nairobi: KIE

31. Narang, M.K. \& Agarwal, J.C. (2011). Inclusive Education; New Delhi: Agarwal Publication

32. Njeri, K, R (2013) analysis of the roles of school management committees in the implementation of inclusive education in public primary schools in kasarani district, Kenya. Unpublished Master Thesis, University of Nairobi.

33. Ogot,O.. (2008). Making primary education meaningfully inclusive.A paper presented at UNECA/LCD in Addisababa, Ethiopia: $20^{\text {th }}-22^{\text {nd }}$ May, 2015

34. Prinsloo, E (2001) Working towards inclusive education in South African classrooms, South African Journal of Education, 2001, 21(4), 344

35. Rachel B. L.(2015). "Acceptance of Persons with Disabilities among Students at SCSU" Culminating Projects inCommunity Psychology, Counseling and Family Therapy. Paper 3.

36. Ryan, H.(2013) ."The Effect of Classroom Environment on Student Learning" (2013). Honors Theses. Paper 2375

37. Salisbury, C. L. (2006). Principals' perspectives on inclusive elementary schools.Research and Practice for Persons with Severe Disabilities, 31 (1), 70-82.

38. Shaddock, A., MacDonald, N., Hook, J., Giorcelli, L., \& Arthur-Kelly, M. (2009). Disability, 
diversity and tides that lift all boats: Review of special education in the ACT. Chiswick, NSW: Services Initiatives

39. Smith, A., \& Thomas, N. (2008). Including pupils with special educational needs and disabilities in national curriculum physical education: A brief review. European Journal of Special Needs Education, 21 (1), 69-83

40. Stainback, S \& Stainback, W. (1996). Inclusion: A guide for educators. Baltimore: Paul H. Brooks Publishing Co.

41. The National Council for Special Education (2010). Literature Review of the Principles and Practices relating to Inclusive Education for Children with Special Educational Needs. Institute of Child Education and Psychology

42. UNESCO, (2005). Guideline for inclusion: Ensuring access to education for all. Paris.

43. UNESCO (2003) Understanding and Responding to Children's Needs in Inclusive Classrooms. New York: United Nation.

44. UNESCO, (2009), Towards Inclusive Education for Children with Disabilities: A Guideline. Bangkok:

45. United Nations Educational, Scientific and Cultural Organization (2009), Towards Inclusive Education for Children with Disabilities: A guideline, UNESCO, Bangkok,

46. Villa, R. A., \& Thousand, J. S. (2009). Restructuring for caring and effective education: Piecing the puzzle together. Baltimore, MD: Paul H. Brooks Publishing.

47. Vorapanya, S(2008). A model for inclusive schools in Thailand. Unpublished PhD dissertation, University of Oregon Graduate School

48. Wanjiku, R., (2004). Factors affecting the implementation of inclusive education policy of Children with special needs in public primary schools in Kiambu District, Kenya. Unpublished M. Ed thesis Nairobi: Kenyatta University.Council for Special Education. 